\title{
The Analysis of Cultural, Architectural and Artistic Factors of the City Image Formation
}

\author{
Olga S. Fedorova* \\ Siberian Federal University \\ 79 Svobodny, Krasnoyarsk, 660041, Russia
}

Received 14.04.2016, received in revised form 10.06.2016, accepted 30.06.2016

\begin{abstract}
Problems of architectural and artistic image of the city have not always occupied leading positions in the national urban planning within theoretical and applied designing. It was related to socio-economic, and sometimes to political conditions for the urban development. In the middle of the 20th century, within the mass housing, architectural and artistic designing was considered needless and wasteful for the state. After the Great Patriotic War it became necessary to build tens of millions of living square meters. As the result of such an unreasonable policy we have got twin cities, "pilot" neighborhoods, similar standard houses, schools, kindergaderns and etc. Over time people faced with the problem of sameness and contradiction in quality: the cities lost their individuality and the society needed an aesthetic satisfaction. The analysis of cultural, architectural and artistic factors has showed that a great significance within the architectural and artistic city image formation is taken by the regional and climatic features, development of the city, urban planning policy, traditions and culture as well as preservation of the existent historical buildings.
\end{abstract}

Keywords: aesthetics, architectural and artistic image, city image, regional and climatic features, originality, city appearance, natural and climatic conditions, historical buildings, architectural heritage.

DOI: 10.17516/1997-1370-2016-9-8-1874-1879.

Research area: culture studies.

A dream about perfect city exited should meet not only pragmatic demands of imagination of many architects, urban planners, a person, be reliable and safe, but also fill the tsars and emperors. Such projects as the Garden City by Sir Ebenezer Howard, the City of the Sun by Campanella, Thomas More and Le Corbusier, the Airplane City by L. Costa and O. Niemeyer bear witness to the vision of ideal city. The visit to Venice inspired Peter the Great with the construction of a beautiful city - SaintPetersburg. Artificially created environment aesthetic feelings and inherent human love to beauty. Practically, in the sphere of modern urban planning the situation is quite different. It is connected with a slight ambiguity in design recommendations, poor scientific studies on this task and dominance of strictly pragmatic, economic and recently commercial aims. In this country, the construction has become a large

(c) Siberian Federal University. All rights reserved

* Corresponding author E-mail address: olga.sibiriachka@yandex.ru 
business with its specific goals and purposes (Krushlinskii, 2003).

Quite often particular and even artistic tasks to plan a building or ensemble fail to appear within the problem of development and uniqueness of the city's character and image. In the modern urban planning the importance of ensemble has been questioned. There is a necessity to determine stages of the image formation at different levels of the project development. One of the most important elements within the problem solution is a detailed investigation of the set of local landscape-ecological as well as natural and climatic conditions. Many outstanding architects always drew inspiration from the nature. A. Gaudi, a famous Spanish architect, said that the nature was the source for his imagination. The wildlife struck the eye of many architects: F. Wright, Le Corbusier, J. Simonds. Nature is the source of beauty; we admire it and aspire to a harmonious coexistence with it. The methods on architecture have been formed for centuries: from the material selection to shaping of buildings, walls, towers and roofs.

Apart from this, there have already been and, moreover, is still being created by the architects and artists new artistic cultures and images. In the national urban planning, particularly in Siberia, where natural and climatic conditions are quite specific and different from other districts of this country, there is a need for evaluation of the natural and climatic conditions influence on the urban formation and shaping quality of engineering.

One of the main tasks for the Urban Development Department set as "Development of architectural-artistic image of the city" (available at http://www.admkrsk.ru/citytoday/building/ Pages/documents.aspx) has been mentioned in major provisions of the city master plan, which not always correspond with the architectural and planning assignments and adopted solutions. At the same time, the theory of urban planning has some uncertainty in interpretations of such terms as "originality", "appearance" and "image" of the city. Obviously, it is explained not only by the complexity and ambiguity of definitions or simplified planning assignment, but also by a very deep influence from, as it would seem, inanimate forms on the human consciousness. But what even more interesting is influence of various sets of local, and as a rule, hard and dangerous natural and climatic conditions on the diversity on architectural forms.

The history of urban planning goes back thousands of years. One of the most remarkable examples of the national urban planning is Moscow as one of the major cities through which one can trace the solution of architectural and artistic challenges. After the overthrow of the Tatar Yoke, Ivan III understood that "the architecture should meet the halo of growing monarchy" (Bunin, 1979). The reconstruction started with the Kremlin. The best architects from Pskov as well as from Italy (Ridolfo "Aristotele" Fioravanti) were invited there. Ivan III the Great wanted the Kremlin to be built with the Russian urban planning traditions, so those architects who were invited from Italy were supposed to study in details the VladimirSuzdal architecture. "Pskovian people, being raised on the architecture of one-headed and five-headed cathedrals of Novgorod and Pskov, brought traditions from the Russian North. Such combination of the Old Russian mixed architectural trends during the construction of Moscow, which had possessed its own architectural heritage, added an original artistic color to the city (Bunin, 1979). Russian monarchs had a good understanding that a true greatness of the capital, its unique image, could be achieved only by applying the best Russian traditions without copying from the European architecture. 
In the end of the $15^{\text {th }}$ century Moscow became a leading center of the Russian architecture and culture. The Church of the Ascension in Kolomenskoye, the Cathedral of Vasily the Blessed, the Ivan the Great Bell Tower are considered as the most outstanding architectural constructions of that time. The appearance of the Cathedral of Vasily the Blessed gives evidence for master skills and brilliance of the architectural manifestation. The problem of capacity was philosophically solved very carefully: the cathedral itself resembles a sanctuary, and the Red Square took on a new function - as a prayer area.

Contemporaries of Ivan III and B. Godunov had a good understanding of the politicoideological meaning of the Cathedral of the Intercession of the Mother of God and the Ivan the Great Bell Tower, which became a "column of Glory" for the triumphant Russian State. Indeed, the politico-ideological and artistic essence of these buildings can explain their extraordinary popularity among book illustrators" (Bunin, 1979).

The accelerated construction on the Russian borders secured Moscow against military attacks. At that time the Kremlin could get a design that earlier was unsuitable for its defensive characteristics. "In 1685, they started overbuilding of all the Kremlin towers in Moscow that re-decorated the Kremlin's shape and had a great impact on the whole Kremlin architecture" (Bunin, 1979). In the 15-17 $7^{\text {th }}$ centuries cities were divided according to their functions into trade and handicraft ones, and into fortresses located particularly in the conquered Siberian territory. At the fortress place selection high hills or islands (half-islands) formed by bends of rivers were preferred. When it came to layouts, so people not only followed the defense conditions, but also obtained a compositional harmony with the environment. For example, the river Neglinka and the Moskva river intersect, making an acute angle, so the Kremlin resembles a triangle in the plan; has monumental walls of the Solovetsky Monastery; the town Sviyazhsk has a round shape and from almost all the sides borders on the White Sea. Across the lowland areas architectures got more freedom to choose the shape for fortresses.

In the pre-Peter Russia streets looked quite different, not so as at the present time. They were formed by the backyards of houses or by fences and, thus, one gets rarely to see buildings' faces. During the reign of Peter the Great, it was decreed that streets must be formed by the front sides of houses. Thus, that order set the modern vision of streets. From the end of the $17^{\text {th }}$ till the middle of $18^{\text {th }}$ century the Russian cities, their appearances in particular, were greatly altered in architectural and artistic senses. The merchants were involved in construction of town halls, schools and orphanages. With advances in the handicraft industry, the percent of craftsmen improved significantly; new types of settlements industrial cities and towns - were built. The Law of 1721 "On seasonal workers" contributed to it. At that period of time, in Saint-Petersburg, the first Commission for Construction, which later was re-organized into the government body for planning of the capital of empire and of principal towns in provinces, was founded. The preestablished general layouts were introduced into the urban planning activity. The civil construction became more prevalent than the church one - a strong focus was on the urban improvement, i.e. on streets cobbling with not only wood coverings, but with stone ones; on road ditches structuring; on tree planting along routes and on roads lightening. The most important change made by Peter the Great was the regular planning applied in urban construction. Such notion as "building line" made its first public appearance; stone construction began its development and green planting had significant progress. The Petrine 
times were a crucial moment in the history of urban planning, which, of course, influenced the change in artistic views of architects.

During the $19^{\text {th }}$ century the Russian architects mastered canons of the Ancient Classics and its artistic development introduced in the cultural heritage of Italian Renaissance (baroque and classicism). The second part of the $19^{\text {th }}$ century was marked by avoidance of ancient canons from the one hand, and by return to a vivid context of the Slavo-Byzantinesque architecture, from the other. The architecture had two tendencies: to associate the formal side of architecture with the function of an object and to express construction features of the buildings under design within the functional content and aesthetic requirements of clients (Ikonnikov, 1971).

In Siberia, the cities construction is resulted from the state activity, new mineral deposits and favorable geographical position. The urban planning in this region is historically related to the development of vast territories. Originally, people built there ostrogs (wooden fortresses), such as Turukhansky Ostrog in 1608, Yeniseisky Ostrog in 1619 or Krasnoyaksky Ostrog in 1628. Places for them were chosen according to strategic considerations - the rivers served as transport routes. Almost all the cities are located on rivers: Krasnoyarsk and Yeniseisk on the Yenisey-river, Irkutsk - on the river Angara, Chita is situated on the Ingola, etc. "Layouts for ostrogs were made under the influence of the state regulations for methods of construction planning, that affected general building techniques and "standard" composition of constructions (Tsariov, 2003: 192). The initial layouts did not change till 1770s; after that, there were taken planning and reconstructive measures based on the principles of regularity. V. I. Tsariov points out, that those traditions which existed before regular planning had a great impact on the further development. In other words, one cannot ignore the planning structure prevailing at that time.

The development of cities was influenced by the construction of Siberian Route in the $18^{\text {th }}$ century. V.I. Tsariov refers to the following tendencies related to this event:

- Settlements were built mostly within the major line of the Siberian Route;

- Intraregional distribution of settlements depended on the specificity of industrial activity of the place (agriculture and mining industry) (Tsariov, 2003).

A great role in the urban development was played by the foundation of the Trans-Siberian Railway in 1890, which contributed to railway stations, workshops, workers' towns and railway bridges. That period laid the basis for industrial development of Krasnoyarsk. Moreover, Siberia was the place for exiled but, at the same time, nobly born criminals, who thus, were quite cultural and educated people. Having settled on a new place, they could not but enrich the atmosphere which surrounded them and share their knowledge and traditions.

During the Great Patriotic War Siberia became a home for many factories, plants research and development institutes, and, thus, for engineers, leading specialists and even workers. Many of them remained living there, that later contributed not only to the growth of Siberian cities, but also to their technological and intellectual potential.

The total industrialization and extensive housing construction also supported the city appearance formation. Clearly, at that period of time the other task was a priority, i.e. to provide housing for all. Still, such a unilateralism lead to the fact, that the cities and new neighborhoods in particular, became "look-alikes" and one could be easily lost in them.

Within the architectural and artistic area in the Siberian cities formation V.I. Krushlinskiim arks a number of patterns: 
1) Aesthetic expression of local features; positive characteristics and neutralization of negative elements are found to be weak. Moreover, there are unreasonably excessive glassed surfaces and south light-type constructions; an artistic solution for the faces, particularly, in popular subdivisions, barely differs from ones in more comfortable districts and common conditions.

2) Many Siberian cities are characterized by incompletion in urban ensembles, by a disrespectful attitude to the near constructions, which leads to a sharp disharmony in the current city's character; uncompleted construction ensembles remain deprived of appeal.

3) Solutions fortheurbanlandimprovement, monumental and decorator design and creation of small architectural forms are non-persistent and do not meet the winter requirements.

4) Creation of the Siberian city image, which implicates with a vivid natural environment and has a sustainable essence from the natural, climatic and historical background, has not been brought to live - the city is created by parts (Krushlinskii, 2003).

Basically, the Siberian cities were built of local materials, i.e. of woods. Only due to forest fires people mastered stone building. Thus, for example, first floors and basement were made of stones. For these purpose, they invited masters and specialists from Western Siberia, who built in the image and likeness of the previously established churches. This is one of the reasons explaining some similarity in Siberian cities (Tsariov, 2003).

A.V. Korzun in her work through the example of Irkutsk observes originality in the planning structure influenced by the following factors:

- natural and geographical conditions: the landscape diversity, advanced river system (the Angara, the Irkut and the Ida) and large forests;

- changes in socio-economic and culturalhistorical conditions for the city development, which determined its vector of growth.

The landscape picturesqueness is typical for the whole Siberian territory. The rock hollows of Sayan Mountains, pre- and transBaikal Ranges, the world's largest rivers $\mathrm{Ob}$, Yenisei, Angara, Lena and the unique Baikal Lake - all they create the impression of a harmony and freedom, of greatness and peace. The landscape of many cities in Siberia gives an opportunity to observe and perceive vast territories. The aspect of picturesque environment deserves a special analysis in the urban planning, since only in its light together with the other natural conditions one can form an individual positive image for the Siberian cities.

Thus, the regional and climatic conditions, history of the city development, urban planning policy, traditions and culture as well as preservation of the current construction have a great importance in the process of architectural city image formation.

\section{References}

Avdotiin, L.N., Smoliar, I.M., Lezhava, I.G. (1989). Gradostroitelnoie proektirovanie [Urban engineering]. Moscow, Stroiizdat, 437p.

Bunin, A.V., Savarenskaja, A.V. (1979). Istoriia gradostroitelnogo iskusstva. Tom 2 [History of urban planning art. Volume 2]. Moscow, Stroiizdat, 533 p.

Gurevich, P.S.(2003). Kulturologiia [Cultural studies]. Moscow, Proekt, 336 p.

Erasov, B.S. (2000). Sotsialnaia kulturologiia [Social culturology]. Moscow, Aspekt Press, 591 p.

Ikonnikov, A.V., Stepanov, G. (1971). Osnovy arkhitekturnoi kompozitsii [Foundations of architectural composition]. Moscow, Iskusstvo, $255 \mathrm{p}$. 
Korzun, A.V. (1984). Razvitie arkhitekturnogo svoeobraziia istoricheskogo goroda (na primere Irkutska): avtoreferat [Development of architectural originality of historic city (through the example of Irkutsk): extended abstract of Cand. Sci. (Architecture) thesis]. Moscow.

Krushlinskii, V.I. (2003). Litso sibirskogo goroda [The face of Siberian city]. Krasnoyarsk, Klaretianum, 158 p.

Silichev, D.A. (1998). Kulturologiia: ucheb. posobie dlia vuzov [Cultural studies: a manual for high schools]. Moscow, PRIOR.

Tsariov, I.V. (2003). Istoriia gradostroitelstva $v$ tsentralnoi Sibiri s drevneishikh vremen do nachala XX veka [History of urban planning in central Siberia from the ancient times till the beginning of the $20^{\text {th }}$ century]. Krasnoyarsk, $208 \mathrm{p}$.

\section{Анализ культурологических \\ и архитектурно-художественных факторов формирования образа города}

\section{О.С. Федорова}

Сибирский федеральный университет Россия, 660041, Красноярск, пр. Свободный, 79

В отечественном градостроительстве в теоретическом и практическом проектировании не всегда занимали лидирующее положение вопросы архитектурно-художественного образа города. Это было связано с сочиально-экономическими, а порой и политическими условиями формирования градостроительства. В середине XX века, в период массового жилищного строительства, архитектурно-художественное проектирование считалось излишеством, напрасно потраченными государственными средствами. После Великой Отечественной войны необходимо было строительство десятков миллионов квадратных метров жилья. В результате такой непродуманной политики вырастали города-близнецьь, «экспериментальные» микрорайоны, одинаковые типовые дома, школь и детские сады и т.д. Со временем возникла проблема однообразия и противоречивости качества, города обезличились, общество стало испытывать потребность в эстетическом удовлетворении. Анализ культурологических и архитектурно-художественных факторов выявил, что большое значение в формировании архитектурно-художественного образа города имеют региональноклиматические особенности, история развития, градостроительная политика, традиции и культура, а также сохранение сложивщейся исторической застройки.

Ключевые слова: эстетика, архитектурно-художественный образ, образ города, региональноклиматические особенности, своеобразие, облик города, природно-климатические условия, историческая застройка, памятники архитектуры.

Научная специиальность: 24.00.00 - культурология. 